\title{
Optimization of Colour Reduction in the Pharmaceutical Effluent by Response Surface Methodology
}

\author{
Ifeoma Maryjane Iloamaeke*, Chineyelu Ijeamaka Egwuatu, Harry Alphonsus Onwumelu, \\ Christian Elochukwu Nzoka-Okoye
}

Department of Pure and Industrial Chemistry, Faculty of Physical Sciences, Nnamdi Azikiwe University, Awka, Anambra State, Nigeria

Email address:

ifeomailoamaeke@yahoo.com (I. M. Iloamaeke), iloamaeke@unizik.edu.ng (I. M. Iloamaeke)

${ }^{*}$ Corresponding author

\section{To cite this article:}

Ifeoma Maryjane Iloamaeke, Chineyelu Ijeamaka Egwuatu, Harry Alphonsus Onwumelu, Christian Elochukwu Nzoka-Okoye. Optimization of Colour Reduction in the Pharmaceutical Effluent by Response Surface Methodology. International Journal of Environmental Chemistry. Special Issue: Efficiency Optimization of Pharmaceutical Effluent Treatment. Vol. 4, No. 1, 2020, pp. 28-37.

doi: $10.11648 /$ j.ijec.20200401.14

Received: March 3, 2020; Accepted: March 24, 2020; Published: April 14, 2020

\begin{abstract}
This research deals with the reduction of colour in the pharmaceutical effluent by Treculia Africans seed coat (TA) as a coagulant using Box behnken design (BBD) from the response surface methodology (RSM). The pharmaceutical effluent was subjected to physicochemical analysis to determine the level of pollution. The coagulant was characterized by Fourier transformed infrared (FTIR) and Scanning electron micrograph (SEM). Result of the physicochemical analysis of the pharmaceutical effluent showed that the colour of the effluent is purple and its $\mathrm{pH}(8.11)$, Hardness $(176 \mathrm{mg} / \mathrm{L})$, phosphate $10.22 \mathrm{mg} / \mathrm{L}$ ) and turbidity $560 \mathrm{mg} / \mathrm{L}$ ) were found to be above WHO permissible limit of effluent disposal. BBD generated 17 experimental run in which coagulation-flocculation process was carried out. These experimental data were analyzed by analysis of variance (ANOVA) and was found to fit $2^{\text {nd }}$ order polynomial model (quadratic equation). The plot of predicted versus actual data confirmed that the model describe explicitly the colour reduction efficiency. The process parameters such as coagulant dosages $(100-500 \mathrm{mg} / \mathrm{L})$, settling time (10-50 minutes) and $\mathrm{pH}(2-10)$ were optimized to get the best treatment condition for colour reduction efficiency. The optimum colour reduction efficiency is $64.36 \%$ at coagulant dosage of 252.32 $\mathrm{mg} / \mathrm{L}$, settling time of 25.31 minutes and $\mathrm{pH}$ of 2.89. The SEM image after treatment suggested that pollutant has been removed from the pharmaceutical effluent since there is change in the surface morphology of the coagulant while FTIR analysis result after treatment proposed removal and addition of bonds due to interaction between the colloid particles of the pharmaceutical effluent and the coagulant. Hence, Treculia Africans seed coat (TA) can serve as alternative coagulant for reduction of colour from Pharmaceutical effluent.
\end{abstract}

Keywords: Pharmaceutical Effluent, Coagulant, Response Surface Methodology, Treculia Africans, Optimization

\section{Introduction}

As the horizon of industrialization is expanding likewise the pollution that emerges from these industries thus this poses a great risk to the ecosystem. Pharmaceutical company is one of the major industries that make use of chemicals in the manufacturing process. Sometimes the effluent that is disposed end up in our rivers, lakes, dams and even on our lands. This effluent may contains high chemical oxygen demand, biological oxygen demand, phosphate, nitrate, chloride, total dissolve solids, total suspended solid, turbidity, colour and heavy metals.
These pose a great danger to aquatic organism, man and the soil because of the pollutants liberated from this effluent. Coagulation-flocculation process is one of the treatment techniques used to treat water and waste water. Studies have shown that this process is cheaper and simple to use [1-4]. Coagulation is the process in which destabilization of particles occurs by the reduction of the repulsive potential of the electrical double layer [5] and flocculation is the phase whereby destabilized particles, or particles formed during destabilization are induced to collect into aggregates. These particles that are destabilized are referred to as colloids and finely divided matter [6]. Coagulation-flocculation takes place in successive steps, 
permitting particle collision and growth of floc followed by sedimentation [7-9]. Coagulant is any substance that when added to water or waste water destabilizes the colloid particles of that water. Stable colloids in water normally present negative charges all around their surface [10]. Coagulants tend to cause the neutralization of these charges, thus colloidal particles become unstable and settle because of gravitational force.

The conventional coagulants that are used are made of up of inorganic and synthetic chemicals which are creating more pollution instead of solving them, hence, the need for natural coagulants. Researchers have opened windows of environmentally benign coagulants that is very much effective when used to purify effluents or water, mention but few are; chitosan [11], Phoenix dactylifera seed [12], Moringa oleifera seeds [13], Cicer arietinum, and Dolichos lablab [14], Drumstick seeds, Tamarind seeds, Neem seeds, Banana peel and sweet potato [15], Dragon fruit foliage [16] and Jackfruit Seed Powder [17].

Treculia Africana is a tree species in the genus Treculia and family Moracene. The species can grow below 1,500 metres $(4,900 \mathrm{ft})$ above sea. The fruits are hard and fibrous, can be the size of a volleyball and weight up to $8.5 \mathrm{~kg}$. It is known in English as African breadfruit in countries like Nigeria, Tanzania, Zambia, Uganda, USA. In Malawi, it is called African boxwood. The Ibos in southern Nigeria called it ' $u k w a$ '. The seeds are used for soup thickening and making bread fruit cakes, snacks and cookies [18, 19].

The aim of this study is to reduce colour in the pharmaceutical effluent using the seed coat of Treculia afaricana (TA), optimizing the coagulation-flocculation process using Response surface methodology by Box behnken design (BBD) and characterizing the pharmaceutical effluent and the TA coagulant.

\section{Materials and Methods}

\subsection{Collection of Samples}

The pharmaceutical effluent was collected from the waste channel of a pharmaceutical industry located at Awka. The effluent collected is purple in colour. While Treculia africiana seed coat (TA) was obtained from Nkpor main market along Onitsha - Enugu expressway, Nkpor, Idemili North Local Government Area, both in Anambra state.

\subsection{Preparation of Coagulant}

The coagulant, Treculia Africana seed coat (TA) was washed and sun dried for 3 days to remove moisture. It was ground to powder, sieved and store for use in dry container.

\subsection{Physicochemical Analysis}

Determination of total suspended solid (TSS), total hardness, chloride, phosphate, nitrate, sulphate chemical oxygen demand (COD), biological oxygen demand (BOD) and total dissolved solid (TDS), were carried out according to the standard method for the examination of water and wastewater [20,21]. Electrical conductivity, turbidity and $\mathrm{pH}$ were determined using electrical conductivity meter Model DDS-307, Turbid meter Lab. Tech. model 038, pH meter Hanna model HI991300.

\subsection{Characterization of the TA Coagulant}

FTIR and SEM of the TA coagulant were done using standard methods and instruments [22].

\subsection{Coagulation-Flocculation Experiment}

The Coagulation-Flocculation experiment was monitored by three factors; settling time from 10 mins, 20 mins, 30 mins, 40 mins and 50 mins, $\mathrm{pH}$ of 2, 4, 6, 8 and 10 and TA dosage from $100 \mathrm{mg} / \mathrm{L}, 200 \mathrm{mg} / \mathrm{L}, 300 \mathrm{mg} / \mathrm{L}, 400 \mathrm{mg} / \mathrm{L}$ and $500 \mathrm{mg} / \mathrm{L}$. This experiment was performed at room temperature, $100 \mathrm{mg}$ of the TA was weighed into $250 \mathrm{~mL}$ beaker and $100 \mathrm{~mL}$ of the effluent at $\mathrm{pH}$ of 2 was added into it. $\mathrm{pH}$ of the effluent was adjusted using $1 \mathrm{M} \mathrm{HCl}$ and $1 \mathrm{M} \mathrm{NaOH}$. The content of the beaker was stirred for 2 mins of rapid mixing $(80 \mathrm{rpm})$ and 2 mins of slow mixing $(20 \mathrm{rpm})$ with a magnetic stirrer and then left undisturbed for 50 mins. It was filtered and the filtrate was subjected to color reduction analysis using UV/VIS spectrophotometer at lambda $(\lambda)$ maximum of $510 \mathrm{~nm}$ (Figure 1) to determine the absorbance and thus colour reduction efficiency is calculated as;

$$
\% \text { colour reduction efficiency }=\frac{\text { Initial absorbance }- \text { final absorbance }}{\text { Initial absorbance }} \times 100 \%
$$

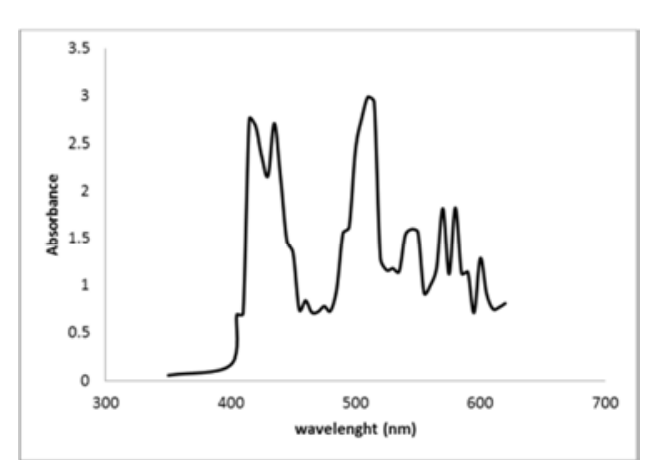

Figure 1. Plot of Absorbance versus wavelength showing the wavelength maximum $\left(\lambda_{\max }\right)$.
The experiment was repeated accordingly as written in Table 2 which is the design matrix of Box-behnken Design (BBD).

\subsection{Response Surface Methodology}

Design expert 11 was used to design the experiment. Here three-level Box-behnken experimental design with categorical factor was employed to study the synergistic effect of the various parameters namely, coagulant dosage $\left(\mathrm{X}_{1}\right)$, settling time $\left(\mathrm{X}_{2}\right)$ and $\mathrm{pH}\left(\mathrm{X}_{3}\right)$ and also to optimize the coagulationflocculation process of TA coagulant as shown in Table 1 and a total of 17 experimental runs were obtained. The experimental design matrix by the Box-Behnken design showing the interaction of the independent variables/factors 
with response as the colour reduction efficiency is tabulated in Table 2. The response variable fitted to $2^{\text {nd }}$ order polynomial (quadratic equation) model as shown in equation (1):

$$
\gamma=\beta_{0}+\sum_{i=1}^{k} \beta_{i} X_{i}+\sum_{i=1}^{k} \beta_{i i} X_{i}^{2}+\sum_{i}^{i<j} \sum_{j} \beta_{i j} X_{i} X_{j}
$$

Where $\gamma$ is the response (colour reduction efficiency) variable to be modeled; $\mathrm{X}_{\mathrm{i}}$ and $\mathrm{X}_{\mathrm{j}}$ the independent variables which influence $\gamma ; \beta_{0}, \beta_{\mathrm{i}}, \beta_{\mathrm{ii}}$ and $\beta_{\mathrm{ij}}$ are the offset terms, the ith linear coefficient, the quadratic coefficient and the ijth interaction coefficient, respectively [23].

Table 1. Factors and levels used in BBD.

\begin{tabular}{llll}
\hline Factors & Lower level & Medium level & High level \\
\hline Coagulant dosage $\left(\mathrm{X}_{1}\right)$ & $100 \mathrm{mg} / \mathrm{L}$ & $300 \mathrm{mg} / \mathrm{L}$ & $500 \mathrm{mg} / \mathrm{L}$ \\
Settling time $\left(\mathrm{X}_{2}\right)$ & 10 minutes & 30 minutes & 50 minutes \\
$\mathrm{pH}\left(\mathrm{X}_{3}\right)$ & 2 & 6 & 10 \\
\hline
\end{tabular}

Table 2. Design Matrix of Box behnken design.

\begin{tabular}{lllll}
\hline Run & Factor $\mathbf{1} \mathbf{X}_{\mathbf{1}}$ : Dosage $(\mathbf{m g} / \mathbf{L})$ & Factor $\mathbf{2} \mathbf{X}_{\mathbf{2}}$ : Settling time (minutes) & Factor $\mathbf{3} \mathbf{X}_{\mathbf{3}}: \mathbf{p H}$ & Colour reduction Efficiency (\%) \\
\hline 1 & 300 & 30 & 6 & 51.43 \\
2 & 500 & 30 & 10 & 35.79 \\
3 & 300 & 50 & 10 & 17.21 \\
4 & 100 & 30 & 2 & 52 \\
5 & 500 & 50 & 2 & 58.82 \\
6 & 100 & 50 & 6 & 20.87 \\
7 & 300 & 10 & 2 & 59.14 \\
8 & 300 & 10 & 2 & 68.45 \\
9 & 500 & 10 & 6 & 38.68 \\
10 & 300 & 10 & 10 & 24.22 \\
11 & 100 & 30 & 6 & 33 \\
12 & 500 & 30 & 6 & 47.86 \\
13 & 300 & 30 & 6 & 51.9 \\
14 & 300 & 30 & 6 & 51 \\
15 & 300 & 30 & 6 & 51.43 \\
16 & 300 & & 6 & 51.43 \\
17 & 100 & 0 & 10 & 10.5 \\
\hline
\end{tabular}

\section{Results and Discussions}

\subsection{Physicochemical Result of the Pharmaceutical Effluent}

Physicochemical result obtained in Table 3 shows that the colour of the effluent is purple thus need for the removal of the colour since colour from pharmaceutical effluent came from colourants added and components mixtures during production of drugs and it has high thermal and photo stability to resist biodegradation when discharged to the environment. Since the final route of effluent is lake, sea, river, dam etc, too much accumulation of this colours on the water bodies can stop the re-oxygenation capacity of the receiving water thus cut-off sunlight, thereby upsetting biological activity in aquatic life and also the photosynthesis process of aquatic plants or algae [24, 25]. From the same Table 3 it can be observed that Hardness, Phosphate and turbidity are all above the standard limit proposed by WHO.

Table 3. Physicochemical result of the pharmaceutical effluent.

\begin{tabular}{lll}
\hline Parameters & Values & WHO Standard \\
\hline Colour & Purpleabsorbance $=\mathbf{5 . 0 7 3}$ & $6.5-8.5$ \\
$\mathrm{pH}$ & 8.11 & 500 \\
$\mathrm{TSS}(\mathrm{mg} / \mathrm{L})$ & 0.16 & 500 \\
$\mathrm{TDS}(\mathrm{mg} / \mathrm{L})$ & 0.36 & 250 \\
$\mathrm{COD}(\mathrm{mg} / \mathrm{L})$ & 66.6 & 500 \\
$\mathrm{BOD}(\mathrm{mg} / \mathrm{L})$ & 172 & 200 \\
Alkalinity $(\mathrm{mg} / \mathrm{L})$ & 60 & 200 \\
Acidity $(\mathrm{mg} / \mathrm{L})$ & 0.0256 & 70 \\
Hardness $(\mathrm{mg} / \mathrm{CaCO})$ & 176 & 40 \\
Nitrate $(\mathrm{mg} / \mathrm{L})$ & 9.19 & 500 \\
Sulphate $(\mathrm{mg} / \mathrm{L})$ & 169.95 & $3.5-5.0$ \\
Phosphate $(\mathrm{mg} / \mathrm{L})$ & 10.022 & 250 \\
Chloride $(\mathrm{mg} / \mathrm{L})$ & 37 & $5-10$ \\
Turbidity $(\mathrm{NTU})$ & 560 & $30-35$ \\
Temperature $\left({ }^{\circ} \mathrm{C}\right)$ & 31.3 & 500 \\
Conductivity $(\mu \mathrm{s} / \mathrm{cm})$ & 179.0 & \\
\hline
\end{tabular}

\subsection{Statistical Analysis from BBD}

The statistical significance of the quadratic model was evaluated by the analysis of variance (ANOVA), as presented in Tables 4. The quadratic equation obtained is given in equation 1 : 


$$
Y=51.44+8.1 X_{1}-4.7 X_{2}-18.84 X_{3}+0.7373 X_{1} X_{2}+4.62 X_{1} X_{3}+0.525 X_{2} X_{3}-9.66 X_{1}^{2}-6.68 X_{2}^{3}-2.5 X_{3}^{2}
$$

Model terms were evaluated by the $p$ value, lack of fit, $\mathrm{F}$ test, coefficient of determination $\left(\mathrm{R}^{2}\right)$ and adequate precision (AP). The term with $p$ values more than 0.05 are insignificant while less than 0.05 is significant (Table 4). In order to develop the regression model that is statistically significant, the insignificant terms in equation 1 as shown in Table 4 were eliminated. The insignificant terms in equation 1 are $X_{1} X_{2}, X_{2} X_{3}$ and $X_{3}^{2}$. These terms have $p$ values more than 0.05 hence are removed to obtain the regression model equation 2. Positive sign in front of these equations indicate synergistic effect of the factors, whereas negative sign indicates antagonistic factor effect [26].

$$
Y=51.44+8.1 X_{1}-4.7 X_{2}-18.84 X_{3}+4.62 X_{1} X_{3}-9.66 X_{1}^{2}-6.68 X_{2}^{3}
$$

$P$ values $<0.05$ for colour reduction demonstrate that the model for those response variables were significant at the $95 \%$ confidence level [26]. F test-value shows that the model is significant. In addition the model exhibited significant lack of fit. Therefore, what measures the overall performance of a model is $\mathrm{R}^{2}$. When predicted $\mathrm{R}^{2}$ and adjusted $\mathrm{R}^{2}$ differ dramatically, there is a good chance that non-significant terms have been included in the model [27]. The predicted $R^{2}$ is 0.7731 and is in reasonable agreement with the adjusted $\mathrm{R}^{2}$ of 0.9857 because their difference is less than 0.2 .
A reliable model should also be able to predict response with a reasonable accuracy when compared with the experimental data. Figures 2 is the plot of Predicted versus Actual data for TA coagulants. It compares experimental colour reduction efficiencies (\%) with the predicted values obtained from the models. The observed points on these plots revealed that the actual values are distributed comparatively near to the straight line, indicating that the regression model is able to predict these colour reduction efficiencies [28-30]. Thus Figure 2 indicated good agreement between the experimental and predicted values.

\section{DESIGN-EXPERT Plot Response}

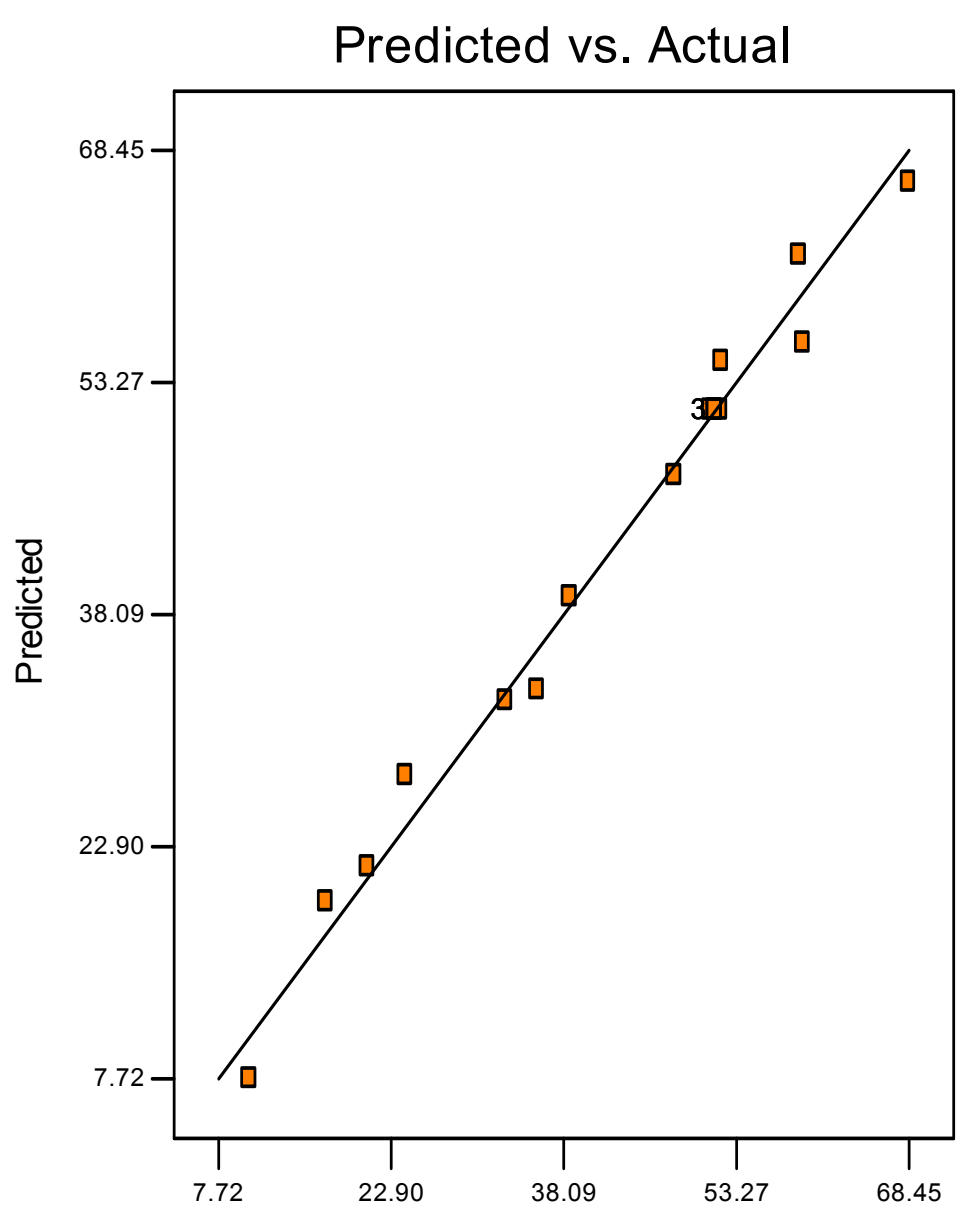

Actual

Figure 2. A plot of Predicted against actual data. 
DESIGN-EXPERT PIot

Response

$X=A$ : Dosage

$\mathrm{Y}=\mathrm{B}$ : Settling time

Actual Factor

$\mathrm{C}: \mathrm{pH}=6.00$

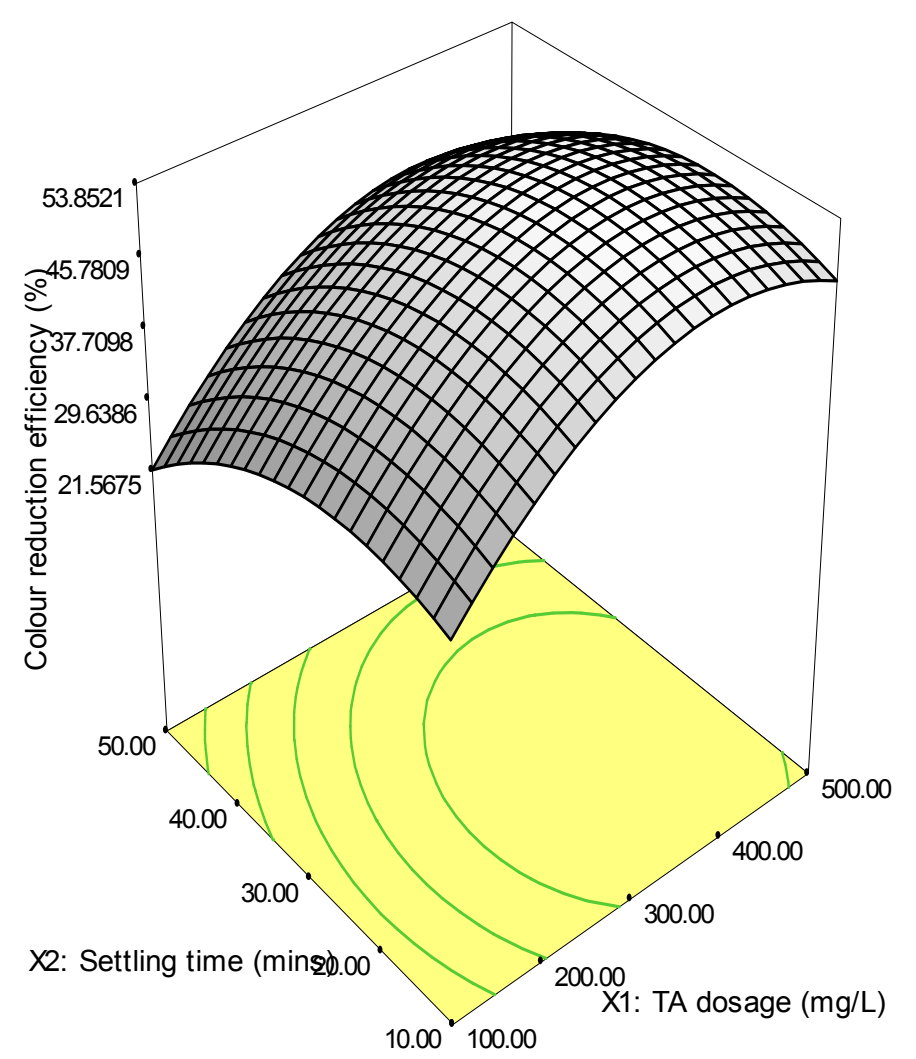

Figure 3. 3D surface interactive effect between Coagulant dosage (TA) and settling time $\left(X_{1} \& X_{2}\right)$ at middle level pH 6.

DESIGN-EXPERT PIOT

Response
$X=A$ : Dosage

$\mathrm{Y}=\mathrm{C}: \mathrm{pH}$

Actual Factor

B: Settling time $=30.00$

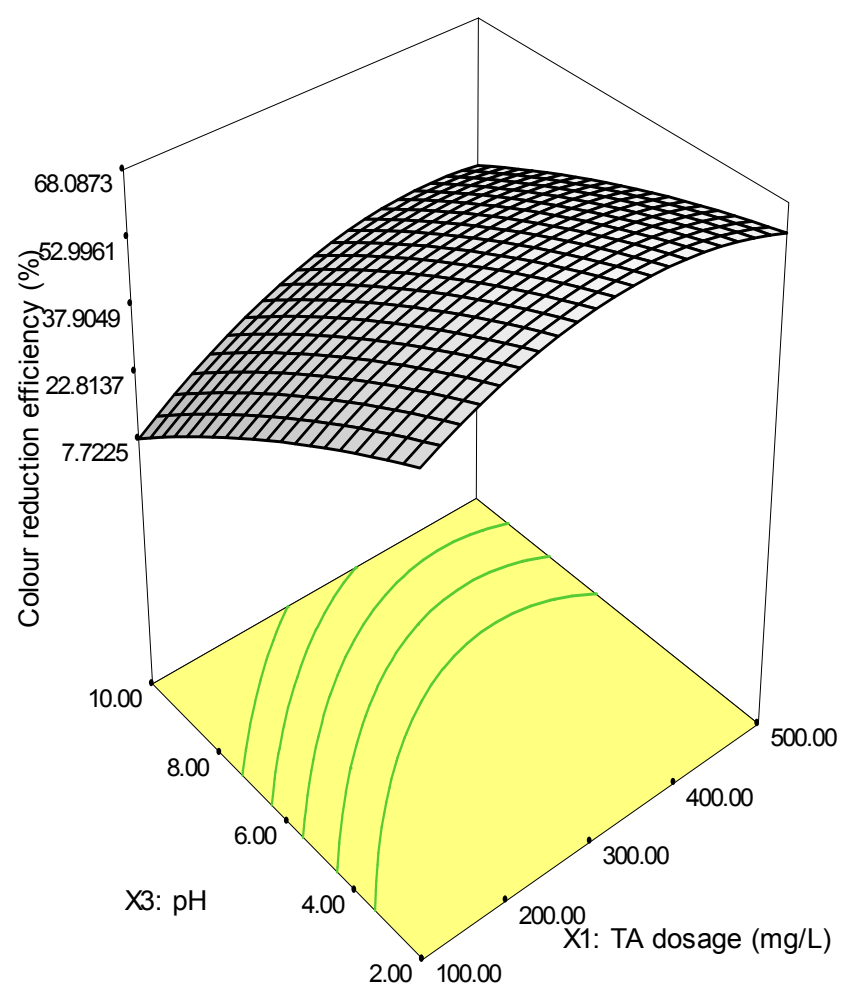

Figure 4. 3D surface interactive effect between coagulant dosage (TA) and $p H\left(X_{1} \& X_{3}\right)$ at middle settling time of 30 mins. 


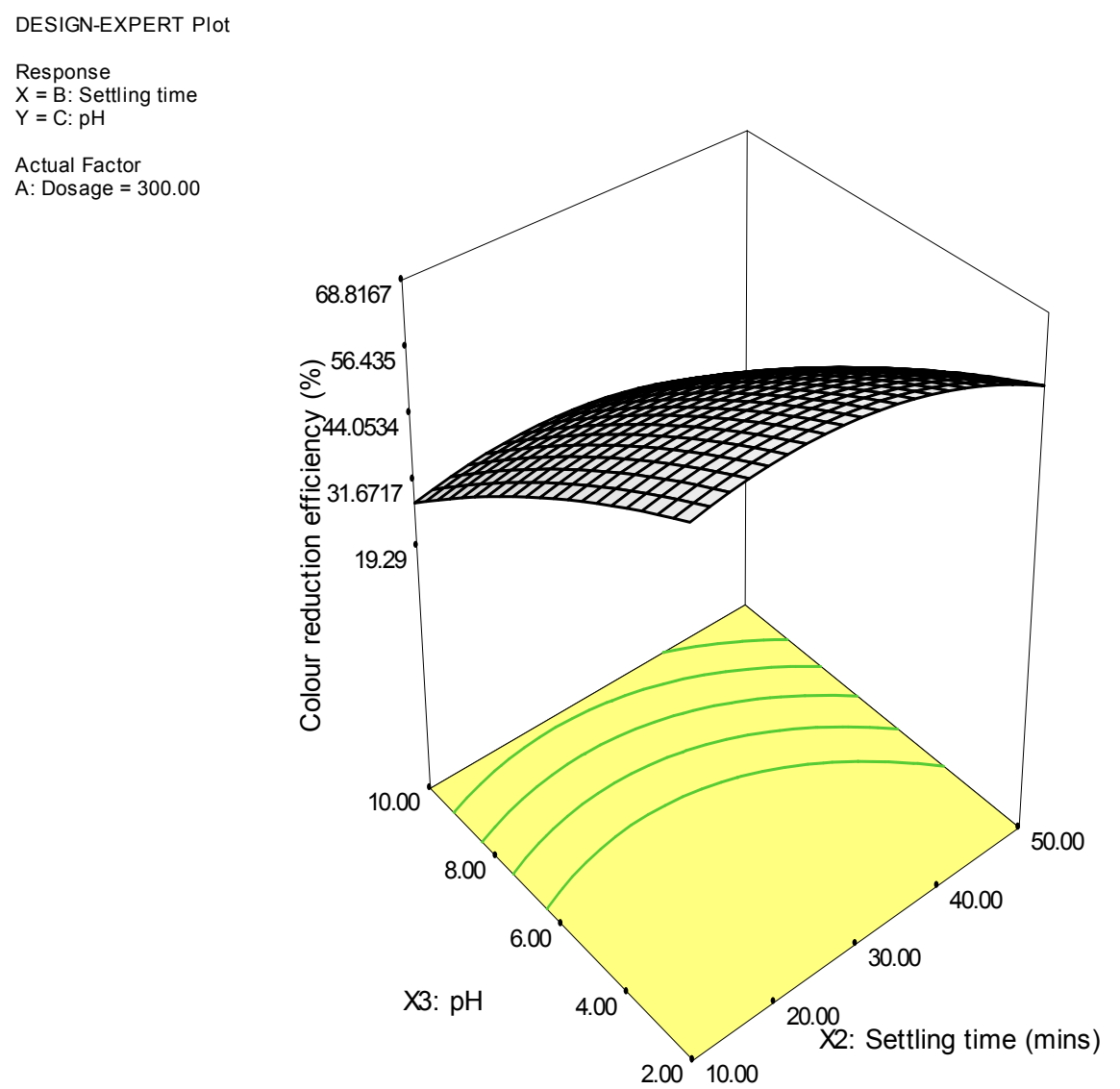

Figure 5. 3D surface interactive effect between settling time and $\mathrm{pH}\left(\mathrm{X}_{2} \& X_{3}\right)$ at middle coagulant dosage of $300 \mathrm{~g} / \mathrm{mL}$.

Table 4. ANOVA for Response Surface Quadratic model for MMM coagulant.

\begin{tabular}{lllllll}
\hline Source & Sum of Squares & df & Mean Square & F-value & p-value \\
\hline Model & 4288.8 & 9 & 476.53 & 53.77 & $<0.0001$ & significant \\
$\mathrm{X}_{1}$ : Dosage & 524.56 & 1 & 524.56 & 59.19 & 0.0001 & \\
$\mathrm{X}_{2}$ : Settling time & 177 & 1 & 177 & 19.97 & 0.0029 & \\
$\mathrm{X}_{3}: \mathrm{pH}$ & 2838.43 & 1 & 2838.43 & 320.27 & $<0.0001$ \\
$\mathrm{X}_{1} \mathrm{X}_{2}$ & 2.18 & 1 & 2.18 & 0.2455 & 0.6354 \\
$\mathrm{X}_{1} \mathrm{X}_{3}$ & 85.29 & 1 & 85.29 & 9.62 & 0.0173 & \\
$\mathrm{X}_{2} \mathrm{X}_{3}$ & 1.32 & 1 & 1.32 & 0.1492 & 0.7108 & \\
$\mathrm{X}_{1}^{2}$ & 392.62 & 1 & 392.62 & 44.3 & 0.0003 & \\
$\mathrm{X}_{2}{ }^{2}$ & 187.83 & 1 & 187.83 & 21.19 & 0.0025 & significant \\
$\mathrm{X}_{3}^{2}$ & 26.4 & 1 & 26.4 & 2.98 & 0.128 & \\
Residual & 62.04 & 7 & 8.86 & & & \\
Lack of Fit & 61.63 & 3 & 20.54 & 202.67 & & $<0.0001$ \\
Pure Error & 0.4055 & 4 & 0.1014 & & & \\
Cor Total & 4350.84 & 16 & & & & \\
$\mathrm{R}^{2}$ & 0.9857 & & & & & \\
Adjusted $\mathrm{R}^{2}$ & 0.9674 & & & & & \\
Predicted $\mathrm{R}^{2}$ & 0.7732 & & & & \\
Adeq Precision & 25.6810 & & & & \\
\hline
\end{tabular}

\subsection{Interactive Effect of the Three Independent Parameters}

The interactive effect of $X_{1}, X_{2}$ and $X_{3}$ were shown on response surface plots, where some variable were kept constant at middle level in Figures 3-5. The response surface plots indicate that the maximum colour removal efficiencies are located inside the design boundary. In Figures 3, 4, and 5, it can be observed that, the colour reduces at the condition where TA dosage is within the range of $200-400 \mathrm{mg} / \mathrm{L}$, and pH 8-2 and settling time of 20-40 mins recorded a little increase in the colour reduction efficiency. TA dosage and $\mathrm{pH}$ in Figures 3, 4 and 5 plays a great part in the colour reduction efficiency. Therefore, TA dosage, $\mathrm{pH}$ and settling time are the significant factors for colour reduction efficiency. Settling time showed very little effect on the colour reduction efficiency and this can be attributed to the coagulationflocculation hydrolysis, which can inhibit the bridging and enmeshment [30]. The mechanism that can be proposed in this coagulation-flocculation process is charge neutralization. The existence of different charges induces mutual attraction 
between particles to spontaneously agglomerate since repulsion force were overcome resulting in an increase in the stability of the suspension. Hence in acidic condition and adequate dosage an increase in the colour reduction efficiency is observed. Where there is an excess TA dosage charge reversal is favoured thus, decrease in the colour reduction efficiency. This result aligned with the result obtained elsewhere [31, 32].

\subsection{Optimization of the Coagulation-flocculation for TA Coagulant}

Numerical optimization was applied from BBD design to obtain a desirable value, optimum process parameters and to achieve highest treatment performance for colour reduction efficiency of TA coagulant used for each input factors and response can be selected. Equation 2 was solved for the best solutions such that the responses $\gamma$ are maximized within the design space. The desirability of 1.00 and optimum condition for colour reduction efficiency is $64.36 \%$ at coagulant dosage of $252.32 \mathrm{mg} / \mathrm{L}$, settling time of 25.31 minutes and $\mathrm{pH}$ of 2.89 were obtained.

To verify the reliability of the regression model, the pharmaceutical effluent was retreated at the optimum conditions in triplicate. The colour reduction efficiency obtained through the experiment is $63.66 \pm 0.42 \%$. This result is close to the predicted value estimated by the BBD, thus this confirms that the RSM approach is suitable for optimizing the operational conditions of the coagulationflocculation process.

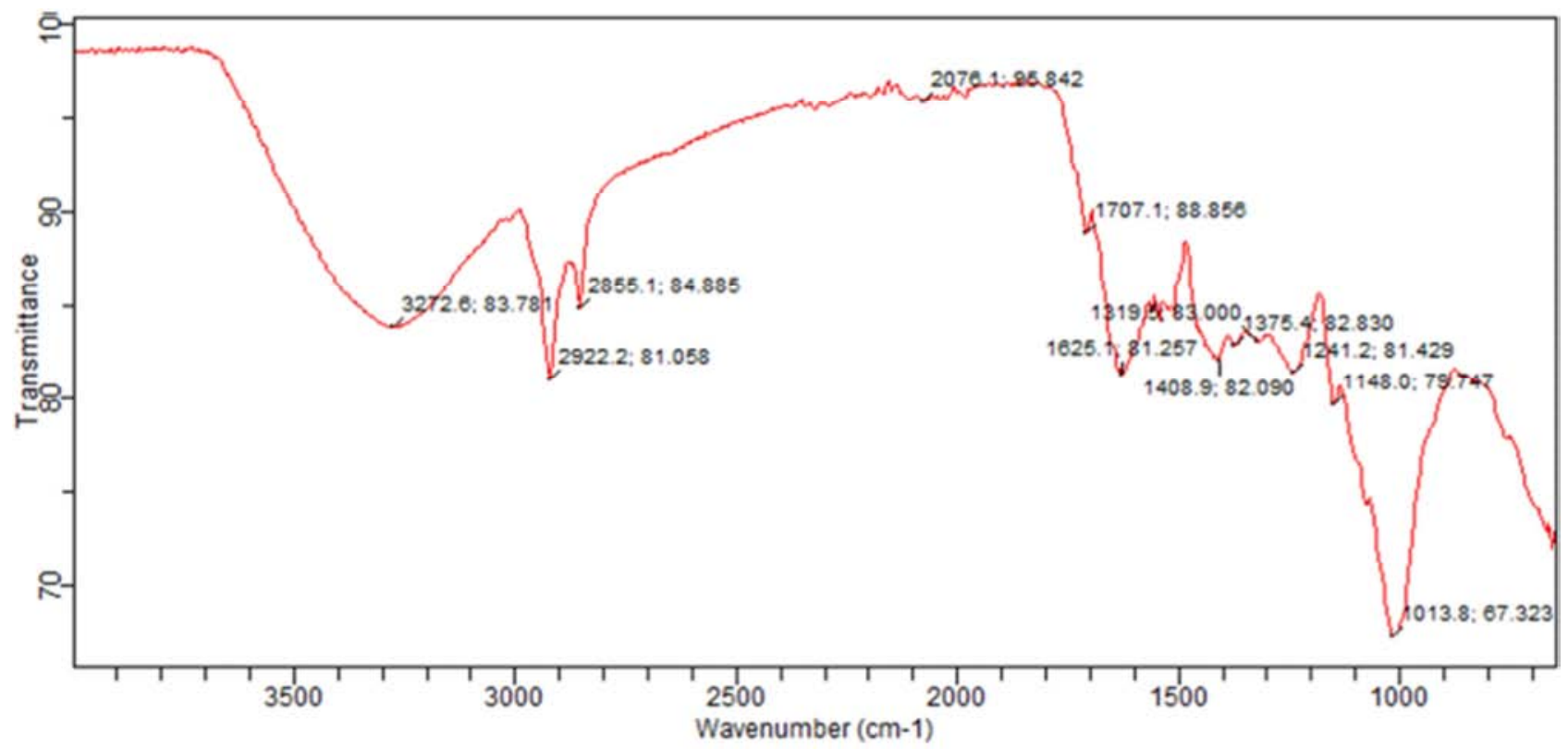

Figure 6. FTIR Spectrum of TA before coagulation-flocculation process.

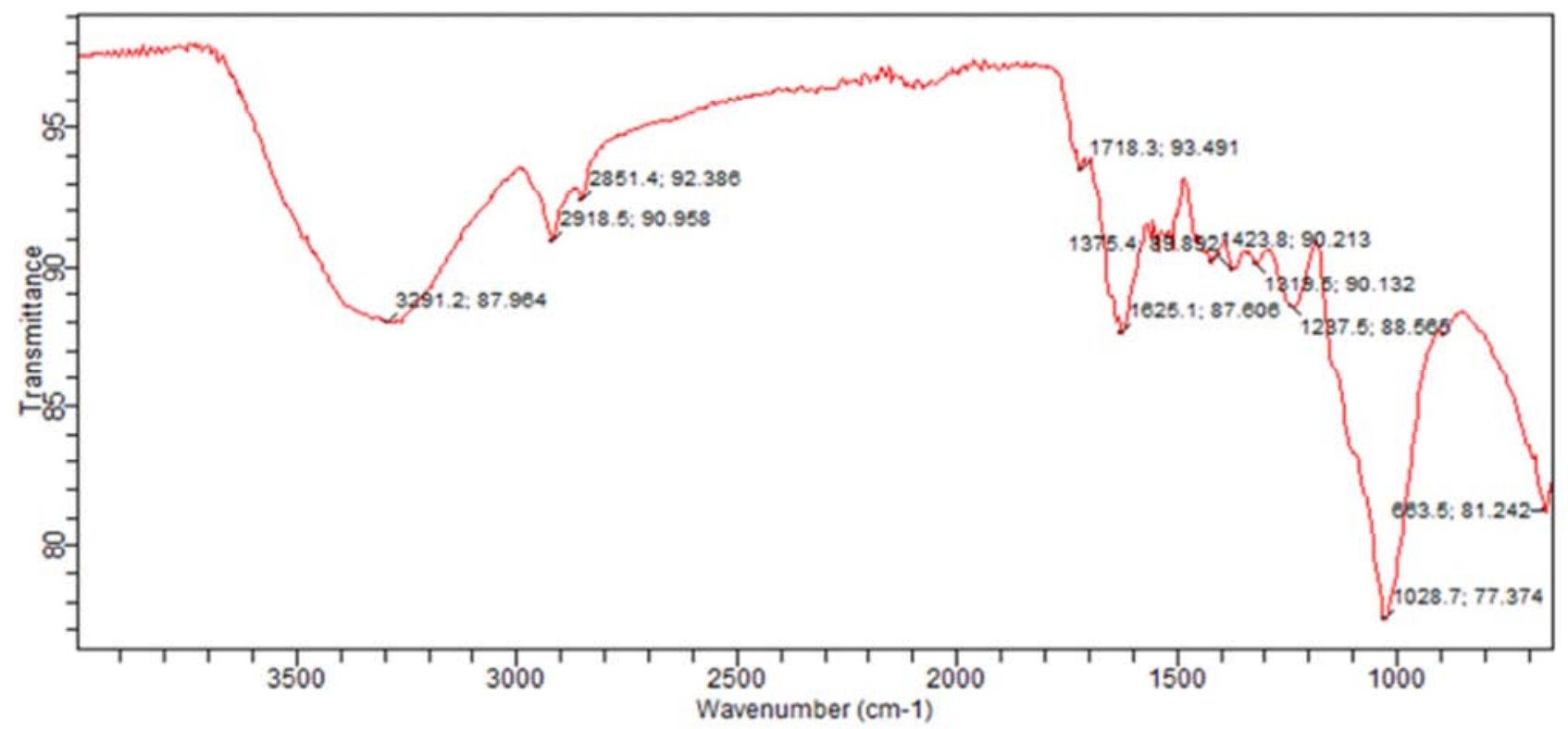

Figure 7. FTIR TA after coagulation-flocculation process. 


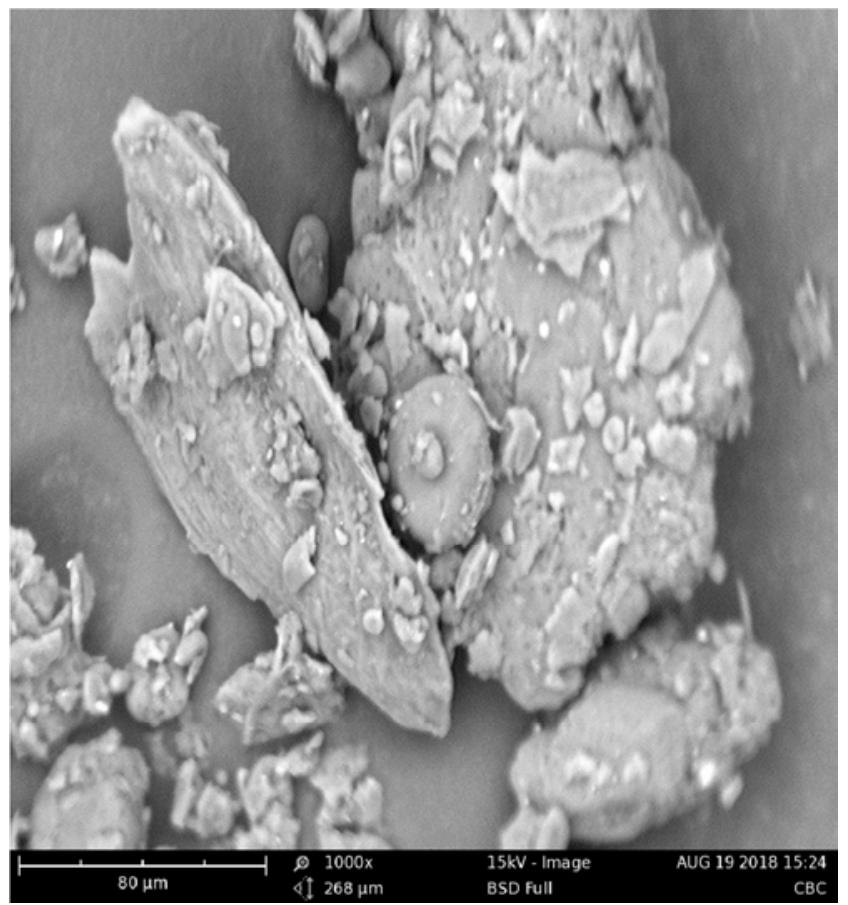

Figure 8. SEM image of TA before Coagulation-flocculation process.

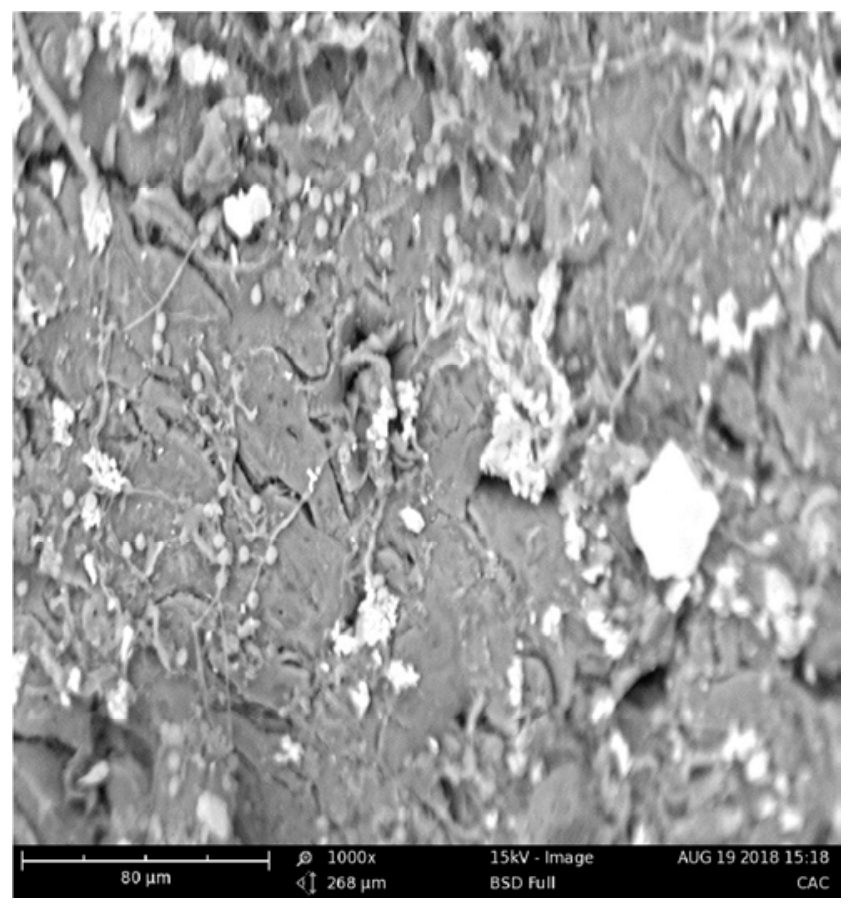

Figure 9. SEM image of TA after Coagulation-flocculation process.

\subsection{Characterization of the TA Coagulant}

FTIR spectra of the TA before and after coagulationflocculation process are shown in Figures 6 and 7. In Figure 6, the peak at $3292.6 \mathrm{~cm}^{-1}$ is an indication of O-H stretch from alcohol, Absorption bands at 2922.2 and $2855.1 \mathrm{~cm}^{-1}$ are $\mathrm{C}-\mathrm{H}$ stretch from alkane. Bands at $2076.1 \mathrm{~cm}^{-1}$ and $1707.1 \mathrm{~cm}^{-1}$ are $\mathrm{N}=\mathrm{C}=\mathrm{S}$ stretch, 1625.1 and $1408.9 \mathrm{~cm}^{-1}$ are $\mathrm{O}-\mathrm{H}$ bending. The peaks at $1375.4,1319.5,1241.2$ and $1148.0 \mathrm{~cm}^{-1}$ are $\mathrm{C}-\mathrm{O}$ stretch and band at $1013.8 \mathrm{~cm}^{-1}$ is referred to as $\mathrm{C}=\mathrm{C}$ bend.
While Figure 7, displays broad and intense peaks as seen in Figure 6 but with some modifications as a result of the interaction of the pollutant including the colour on the surface of the TA coagulant. Absorption band at $3291.2 \mathrm{~cm}^{-1}$ demonstrated O-H stretch, 2918.5 and $2851.4 \mathrm{~cm}^{-1}$ are C-H stretch, $1718.3,1625.1,1423.8,1319.5$ and $1237.5 \mathrm{~cm}^{-1}$ are O$\mathrm{H}$ bend. The peak at $1028.7 \mathrm{~cm}^{-1}$ is $\mathrm{C}-\mathrm{O}$ stretch. Comparing Figures 6 and 7, it can be inferred that after the coagulationflocculation process, there were shift and removal of the absorption bands in the spectral bands indicating an interaction between the colloid particles of the pharmaceutical effluent and that of the TA coagulant hence the shifting and removal of some functional groups.

SEM image of TA coagulant before and after coagulationflocculation process are shown in Figures 8 and 9. In Figure 8 , the SEM image shows that the coagulant has rough edges and vacant spaces which is called pores while in Figure 9, the pores and edges has been occupied by the colloid particles of the pharmaceutical effluent. The change in the surface morphology of the coagulant after the treatment indicates the adsorption of pollutants on the surface of the coagulant hence TA can be used as a bio-coagulant in the colour reduction of the pharmaceutical effluent.

\section{Conclusion}

The study has shown that response surface methodology by BBD optimized the colour reduction efficiency. ANOVA report stated that the $2^{\text {nd }}$ order polynomial (quadratic) equation is the best model for this process. All the independent variables tested such as coagulation dosage, settling time and $\mathrm{pH}$ showed significant interaction and contributed to the increase in the colour reduction efficiency. The best $\mathrm{pH}$ condition was found to be at acidic medium. From the result of FTIR and SEM analysis it can be suggested that what brought about the reduction of the purple colour of the pharmaceutical effluent treated with TA coagulant is the surface chemistry of the TA coagulant.

\section{References}

[1] G. Wolf, R. M. Schneider, M. C. Bongiovani, E. M. Uliana, A. Garcia do Amaral (2015). Application of Coagulation/Flocculation Process of Dairy Wastewater from Conventional Treatment Using Natural Coagulant for Reuse. Chemical Engineering Transactions, vol. 4, pp. 2041-2046.

[2] T. Zayas, V. Romero, L. Salgado, M. Meraz, U. Morales (2007). Applicability of coagulation/flocculation and electrochemical processes to the purification of biologically treated vinasse effluent. Separation and Purification Technologyvol. 57, 270-276.

[3] A. L. Ahmad, S. S. Wong, T. T. Teng, A. Zuhairi (2007). Improvement of alum and $\mathrm{PACl}$ coagulation by polyacrylamides (PAMs) for the treatment of pulp and paper mill wastewater. Chemical Engineering Journalvol. 137, pp. $510-517$. 
[4] J. D. P. Theodoro; G. F. Lenz; R. F. Zara, R. Bergamasco (2013) Coagulants and Natural Polymers: Perspectives for the Treatment of Water. Plastic and Polymer Technology (PAPT), vol. 2 Issue 3, pp. 55-62.

[5] S. D. Faust, and O. M. Aly, (1983). Chemistry of Water Treatment, Butterworth publishers, Stoneham, pp. 277-363.

[6] A. Amirtharajah, and C. R. O’Melia. (1999). In water quality and treatment AWWA, $5^{\text {th }}$ ed. American Water Works Association. Denver Co. p. 35.

[7] J. Bratby (2006). Coagulants, in Coagulation and Flocculation in Water and Wastewater Treatment, 2nd ed., IWA Publishing, London, pp. 50-68.

[8] P. Ghorbannezhad, A. Bay, M. Yolmeh, R. Yadollahi \& J. Y. Moghadam (2016): Optimization of coagulation-flocculation process for medium density fiberboard (MDF) wastewater through response surface methodology, Desalination and Water Treatment, DOI: 10.1080/19443994.2016.1170636, pp. 1-17.

[9] N. B. Prakash, V. Sockan, P. Jayakaran (2014). Waste Water Treatment by Coagulation and Flocculation. International Journal of Engineering Science and Innovative Technology, vol. 3, issue 2, pp. 479-484.

[10] J. Beltrán-Heredia, J. Sánchez-Martín, M. A. Dávila-Acedo (2010). Optimization of the synthesis of a new coagulant from a tannin extract. Journal of Hazardous Materials, vol. 186 issue 2011, pp. 1704-1712.

[11] R. Krishna, O. Sahu (2013). Reduction of COD and Color by Polymeric Coagulant (Chitosan). Journal of Polymer and Biopolymer Physics Chemistry, 2013, Vol. 1, No. 1, pp. 22-25.

[12] I. M. Iloamaeke and C. O. Julius (2019). Treatment of Pharmaceutical Effluent Using Seed Of Phoenix Dactyliferaas a Natural Coagulant. Journal of Basic Physical Research, Vol. 9, No. 1 pp. 91-100.

[13] S. Bhatia, Z. Othman, A. L. Ahmad (2006). Pretreatment of palm oil mill effluent (POME) using Moringaoleiferaseeds as natural coagulant. Journal of Hazardous Materials, vol. 145, issue2007, pp. 120-126.

[14] Md. Asrafuzzaman, A. N. M. Fakhruddin, and Md. Alamgir Hossain (2011). Reduction of Turbidity of Water Using Locally Available Natural Coagulants. International Scholarly Research Network ISRN Microbiology Vol. 2011, Article ID 632189, 6 pages.

[15] P. Ramesh, V. Padmanaban, and R. Sivacoumar (2015). Influence of Homemade Coagulants on the Characteristics of Surface Water Treatment: Experimental Study. International Journal of Engineering Research \& Technology (IJERT), Vol. 4 Issue 12, pp. 342-345.

[16] M. R. Shafad, I. S. Ahamad, A. Idris, Z. Zainal Abidin (2013). A Preliminary Study on Dragon Fruit Foliage as Natural Coagulant for Water Treatment International Journal of Engineering Research \& Technology (IJERT), Vol. 2 Issue 12, pp. 1057-1063.

[17] Aneesu Rahman, Aswathy Ramesh, Ranjitha O R, Suranya T, Jency Nadayil (2018). Efficiency of Jackfruit Seed Powder as a Natural Coagulant. International Research Journal of Engineering and Technology (IRJET), vol. 05, Issue: 03, pp. 3060-3062.

[18] O. Kingsley, O. O. Iyere and E. O. Georgina (2011). Effects of Aqueous Root Extract of Treculiaafricanaon Glucose, Serum Enzymes and Body Weight of Normal Rabbits. British Journal of Pharmacology and Toxicology vol. 2, issue 4, pp. 159-162.

[19] V. N. Osabor, D. A. Ogar, P. C. Okafor and G. E. Egbung (2009). Profile of the African Bread Fruit (Treculia Africana). Pakistan Journal of Nutrition vol. 8, issue 7, pp. 1005-1008.

[20] APHA, AWWA, and WEF (2012) Standard Methods for the Examination of Water and Wastewater. 22nd Edition, New York.

[21] Association of Official Analytical Chemists (AOAC). Official Methods of Analysis of AOAC International, 17th ed.; AOAC International: Gaithersburg, MD, USA, 2000.

[22] U. Ameh. (2006). "Standard Operating Procedure National Agency for Food and Drug Administration and Control (NAFDAC) Boriki Port Hacourt, Nigeria”. PP 07/14. Heinemann Medical Books Ltd.: New York, NY. 122, 184.

[23] Jian-Ping Wang, Yong-Zhen Chen, Xue-Wu Ge, Han-Qing $\mathrm{Yu}$ (2007). Optimization of coagulation-flocculation process for a paper-recycling wastewater treatment using response surface methodology. Colloids and Surfaces A: Physicochem. Eng. Aspects vol., 302, issue 2007, pp. 204-210.

[24] Samchetshabam Gita, Ajmal Hussan, T. G. Choudhury (2016) Impact of Textile Dyes Waste on Aquatic Environments and its Treatment. Environment \& Ecology vol. 35, issue 3C, pp, $2349-2353$.

[25] C. Zaharia, D. Suteu, A. Muresan, R. Muresan, A. Popescu (2009). Textile waste water tretment by homogenous oxidation with hydrogen peroxide. Environ EngManag. J., vol., 8, pp. 1359-1369.

[26] Fakhri (2014). Application of response surface methodology to optimize the process variables for fluoride ion removal using maghemite nanoparticles. Journal of Saudi Chemical Society, vol. 18, pp. 340-347.

[27] K. T. Thuy, and S. K. Lim (2011). Response Surface Methodological approach to optimize the coagulationflocculation process in drinking water treatment. Chemical engineering research and design, vol. 89, pp. 1126-1135.

[28] L. Ahmad, S. Ismail, and S. Bhatia (2005). Optimization of Coagulation-Flocculation Process for Palm Oil Mill Effluent Using Response Surface Methodology. Environmental Science \& Technology, vol. 39, pp. 2828-2834.

[29] J. P. Wang, Y. Z. Chen, Y. Wang, S. J. Yuan, H. Q. Yu (2011). Optimization of the coagulation-flocculation process for pulp mill wastewater treatment using a combination of uniform design and response surface methodology. WaterResearch, vol. 45 , pp. 5633-5640.

[30] H. Zheng, J. Ma, J. Zhai, C. Zhu, X. Tang, Y. Liao, L. Qian\& Y. Sun (2013). Optimization of flocculation process by response surface methodology for diethyl phthalate removal using anionic polyacrylamide. Desalination and Water Treatment, vol. 52, pp. 5390-5400.

[31] Safia Syazana Mohtar, Tengku Nur Zulaikha, Tengku Malim Busu, Ahmad Mujahid Md. Noor, Norsalliana Shaari, Nor Aida Yusoff1, Mohd Azizi Che Yunus, Hanapi Mat (2016). Optimization of coag-flocculation processes of a newly synthesized quaternized oil palm empty fruit bunch cellulose by response surface methodology toward drinking water treatment process application. Clean Techn Environ Policy, pp. 1-14. 
[32] M. Nourani, M. Baghdadi, M, Javan, G. N. Bidhendi (2016) Production of a biodegradable flocculant from cotton and evaluation of its performance in coagulation-flocculation of kaolin clay suspension: optimization through response surface methodology (RSM). J Environ Chem Eng., vol. 4, issue 2, pp. 1996-2003. 